Article

\title{
The Mutant p53-Driven Secretome Has Oncogenic Functions in Pancreatic Ductal Adenocarcinoma Cells
}

\author{
Giovanna Butera ${ }^{1}$, Jessica Brandi ${ }^{2}$, Chiara Cavallini ${ }^{3}$, Aldo Scarpa ${ }^{4,5}$ () Rita T. Lawlor ${ }^{5}$, \\ Maria Teresa Scupoli 1,3, Emílio Marengo 6,7, Daniela Cecconi ${ }^{2}$, Marcello Manfredi ${ }^{7,8, *}$ \\ and Massimo Donadelli $1, *$ (B)
}

1 Department of Neurosciences, Biomedicine and Movement Sciences, Section of Biochemistry, University of Verona, Strada Le Grazie 8, 37134 Verona, Italy; giovanna.butera@univr.it (G.B.); mariateresa.scupoli@univr.it (M.T.S.)

2 Department of Biotechnology, University of Verona, 37134 Verona, Italy; jessica.brandi@univr.it (J.B.); daniela.cecconi@univr.it (D.C.)

3 Research Center LURM (Interdepartmental Laboratory of Medical Research), University of Verona, 37134 Verona, Italy; chiara.cavallini@univr.it

4 Department of Diagnostics and Public health, Section of Pathology, University of Verona, 37134 Verona, Italy; aldo.scarpa@univr.it

5 ARC-Net Centre for Applied Research on Cancer, University and Hospital Trust of Verona, 37134 Verona, Italy; rita.lawlor@arc-net.it

6 Department of Sciences and Technological Innovation, University of Piemonte Orientale, 28100 Novara, Italy; emilio.marengo@uniupo.it

7 Center for Translational Research on Autoimmune and Allergic Diseases, University of Piemonte Orientale, Italy, ISALIT, Spin-off at the University of Piemonte Orientale, 28100 Novara, Italy

8 Department of Translational Medicine, University of Piemonte Orientale, Italy, CAAD, corso Trieste 15/A, 28100 Novara, Italy

* Correspondence: marcello.manfredi@uniupo.it (M.M.); massimo.donadelli@univr.it (M.D.); Tel.: +39-032-1660810 (M.M.); +39-045-8027281 (M.D.); Fax: +39-045-8027170 (M.D.)

Received: 2 May 2020; Accepted: 5 June 2020; Published: 9 June 2020

check for updates

\begin{abstract}
The cancer secretome is a rich repository of useful information for both cancer biology and clinical oncology. A better understanding of cancer secretome is particularly relevant for pancreatic ductal adenocarcinoma (PDAC), whose extremely high mortality rate is mainly due to early metastasis, resistance to conventional treatments, lack of recognizable symptoms, and assays for early detection. TP53 gene is a master transcriptional regulator controlling several key cellular pathways and it is mutated in $\sim 75 \%$ of PDACs. We report the functional effect of the hot-spot p53 mutant isoforms $\mathrm{R} 175 \mathrm{H}$ and $\mathrm{R} 273 \mathrm{H}$ on cancer cell secretome, showing their influence on proliferation, chemoresistance, apoptosis, and autophagy, as well as cell migration and epithelial-mesenchymal transition. We compared the secretome of p53-null AsPC-1 PDAC cells after ectopic over-expression of R175H-mutp53 or R273H-mutp53 to identify the differentially secreted proteins by mutant p53. By using high-resolution SWATH-MS technology, we found a great number of differentially secreted proteins by the two p53 mutants, 15 of which are common to both mutants. Most of these secreted proteins are reported to promote cancer progression and epithelial-mesenchymal transition and might constitute a biomarker secreted signature that is driven by the hot-spot p53 mutants in PDAC.
\end{abstract}

Keywords: mutant p53; pancreatic adenocarcinoma; secretome; proteomics; oncogenes; gain-of-function

\section{Introduction}

Pancreatic ductal adenocarcinoma (PDAC) is the most common type of pancreatic cancer; it is characterized by poor prognosis, with a dismal overall five-year survival rate of $\sim 5 \%[1,2]$. A typical 
feature of PDAC is the lack of early phase specific symptoms that leads to a late-stage diagnosis. In addition, the absence of early biomarkers, detection methods, and chemoresistance are the main drivers of poor prognosis in PDAC [3,4]. Chemoresistance is primarily caused by key genetic alterations, which favour disorders in the apoptotic pathway [3]. One of the most important proteins involved in DNA damage repair and apoptosis is the tumor suppressor protein p53 (TP53), which regulates a wide range of cellular biological processes to prevent tumor formation by killing or delaying the growth of neoplastic cells [5]. The importance of the p53 pathway in tumor suppression is also highlighted by the observation that TP53 mutations are associated to poor prognosis [6] and they are present in about half of all human cancers, reaching even $\sim 75 \%$ of PDAC patients $[7,8]$. The great majority of p53 alterations are missense mutations that are localized in the DNA binding domain, which result in the expression of full-length mutant p53 isoforms [9]. The most frequent p53 alterations are missense mutations in the DNA binding domain (DBD), called hot-spot mutants, which cause the expression of full-length p53 mutant isoforms. These mutations in the DBD are grouped into two main types: conformational mutations, such as mutp53-R175H, and contact mutations, such as mutp53-R273H, which cause structural modifications in the binding domain or affect the DNA binding ability of the protein, respectively [10]. Both kinds of mutations alter p53's interaction with its consensus DNA-binding sequence, negatively impacting the activation of tumor suppressor wild type-p53 target genes.

In addition, these mutants can acquire new oncogenic functions and they are named gain-of-function (GOF) mutants. In fact, although they lose the capability to bind DNA and regulate wtp53-target genes, they can regulate the transcription of a different set of genes that induce cancer aggressiveness. This is achieved through direct interaction with various transcription factors or repressors in the transcriptional complex. This results in the development of the typical hallmarks of cancer cells carrying the mutant TP53 gene, such as chemoresistance [11], metabolic alterations [12,13], and genomic instability [14]. Furthermore, mutant p53 isoforms strongly accumulate in cells as a result of a reduction in the rate of mutant p53 protein degradation due to its inability to induce the E3 ubiquitin-protein ligase MDM2 [15], thus amplifying the oncogenic effects of the protein.

Many recent studies reveal the role of p53 mutant proteins in the modification of the tumor microenvironment and secretome of cancer cells, altering the secretion of inflammatory cytokines, affecting the crosstalk between cancer and stromal cells, and increasing the extracellular acidification [16-18]. Cancer aggressiveness is strongly dependent on the composition of the extracellular microenvironment, which is itself affected by the release of proteins by the cancer cells. Indeed, secreted proteins may promote carcinogenesis, favoring key roles, such as cell signaling, communication and migration $[19,20]$. Thus, the secretome of cancer cells represents an unique opportunity to collect and identify several secreted macromolecules and may be considered a valuable source for biomarker discovery and the identification of novel therapeutic targets [18,21].

In the present study, we investigate the functional effect of mutp53-driven secretome of PDAC cells, demonstrating its impact on several hallmarks of cancer cells carrying the mutant TP53 gene, such as hyper-proliferation, chemoresistance, inhibition of apoptosis and autophagy, cell migration, and epithelial-to-mesenchymal transition. In order to identify a mutp53-dependent signature of secreted proteins by PDAC cells, a proteomics approach has been used. We identified 15 hypo- or hyper-secreted proteins in common to both $\mathrm{R} 175 \mathrm{H}$ and $\mathrm{R} 273 \mathrm{H}$ hot-spot mutant p53 isoforms. These results definitively clarify the functional impact of mutp53-driven secretome in PDAC aggressiveness and provide crucial insights on the identification of mutp53-dependent PDAC secretome.

\section{Materials and Methods}

\subsection{Chemicals}

Gemcitabine (2',2'-difluoro-2'-deoxycytidine; GEM) was provided by Accord Healthcare (Milan, Italy) and it was solubilized in sterile water. 


\subsection{Cell Culture}

PDAC cell line AsPC-1 (p53-null) was grown in RPMI 1640, while lung cancer cell line H1299 (p53-null) was cultured in DMEM medium (Life Technologies, Milan, Italy). Both culture media were supplemented with $10 \%$ FBS, and $50 \mu \mathrm{g} / \mathrm{mL}$ gentamicin sulfate (BioWhittaker, Lonza, Bergamo, Italy). AsPC1 was purchased by ATCC (Manassas, VA, USA), while both of the mock clone and clone stably expressing mutant p53-R273H of the p53-null H1299 cells were kindly provided by Dr. Riccardo Spizzo (Centro di Riferimento Oncologico, National Cancer Institute, Aviano, Italy). The adherent cells were incubated at $37^{\circ} \mathrm{C}$ with $5 \% \mathrm{CO}_{2}$.

\subsection{Transient Transfection Assay}

AsPC-1 cells were seeded in 96-well or in six-well plates. Wild type or mutant $\mathrm{p} 53$ ectopic expression in p53-null cancer cells was obtained by transfecting pcDNA3-mutp53R273H, pcDNA3-mutp53R175H, or pCMV-wild type p53 expression vectors or their relative negative control ( $p c D N A 3$ or pCMV). Transfections were carried out using Lipofectamine 3000 (Thermo Fisher Scientific, Milan, Italy) for $48 \mathrm{~h}$, according to the manufacturer's instructions.

\subsection{Cell Proliferation Assay}

AsPC-1 cells were seeded in 96-well plates $\left(8 \times 10^{3}\right.$ cells/well). Forty-eight hours later, cell growth was measured by Crystal Violet assay (Sigma, Milan, Italy) according to the manufacturer's protocol, and the absorbance was measured by spectrophotometric analysis $\left(\mathrm{A}_{595} \mathrm{~nm}\right)$.

\subsection{Apoptosis Assay}

The cells were seeded in 96-well plates $\left(8 \times 10^{3}\right.$ cells/well). Forty-eight hours later, cells were fixed with $2 \%$ paraformaldehyde in PBS for $15 \mathrm{~min}$. at room temperature, washed twice with PBS, and then stained with annexinV/FITC (Bender MedSystem, Milan, Italy) in binding buffer (10 mM HEPES/NaOH pH 7.4, $140 \mathrm{mM} \mathrm{NaCl}$, and $2.5 \mathrm{mM} \mathrm{CaCl}_{2}$ ) for $10 \mathrm{~min}$. at room temperature in the dark. The cells were then washed with binding buffer and fluorescence was measured using a multimode plate reader $\left(\mathrm{Ex}_{485} \mathrm{~nm}\right.$ and $\mathrm{Em}_{535} \mathrm{~nm}$ ) (GENios Pro, Tecan, Milan, Italy). The values were normalized on cell proliferation by Crystal Violet assay.

\subsection{Autophagosome Formation Assay}

The cells were stained with the fluorescent probe monodansylcadaverine (MDC; Sigma, Milan, Italy) to quantify the induction of autophagy, since MDC is a maker for acidic vesicular organelles (AVOs), as autophagic vacuoles and autolysosomes. Briefly, cells were seeded in 96-well plates $\left(5 \times 10^{3}\right.$ cells/well $)$ and, $48 \mathrm{~h}$ later, cells were incubated in culture medium containing $50 \mu \mathrm{M}$ MDC at $37^{\circ} \mathrm{C}$ for $15 \mathrm{~min}$. Cells were then washed with Hanks buffer (20 mM Hepes pH 7.2, $10 \mathrm{mM}$ glucose, $118 \mathrm{mM} \mathrm{NaCl}, 4.6 \mathrm{mM} \mathrm{KCl}$, and $\left.1 \mathrm{mM} \mathrm{CaCl}_{2}\right)$ and fluorescence was measured using a multimode plate reader $\left(\mathrm{Ex}_{340} \mathrm{~nm}\right.$ and $\mathrm{Em}_{535} \mathrm{~nm}$ ) (GENios Pro, Tecan, Milan, Italy). The values were normalised on cell proliferation by Crystal Violet assay.

\subsection{Wound-Closure Cell Migration Assay}

AsPC-1 cells were seeded in six-well plate $\left(6 \times 10^{5}\right.$ cells/well). A scratch was made across the center of the AsPC1 p53-null monolayer cells using a sterile $200-\mu \mathrm{L}$ pipette tip. Subsequently, the cells were washed with PBS to remove the detached cells and incubated with conditioned medium (CM) released by transfected AsPC-1 cells for $48 \mathrm{~h}$. Cell migration was observed in time-lapse (EVOS). Images of cells movement were captured every $2 \mathrm{~h}$ for $48 \mathrm{~h}$ and were further analyzed quantitatively using NIH ImageJ computing software (http://rsb.info.nih.gov/nih-image/). Migration ability as relative migration distance (RMD) was evaluated using the following formula: RMD (\%) = $100(\mathrm{~A}-\mathrm{B}) / \mathrm{A}$, with $\mathrm{A}$ and $\mathrm{B}$ representing the width of cell scratches at time 0 and after $48 \mathrm{~h}$ of incubation, respectively. 


\subsection{FACS Analysis}

The cells were trypsinized, washed with PBS, and then incubated with anti-human CD325 (N-Cadherin) antibody that was conjugated with PE (BioLegend, San Diego, CA, USA; Clone 8C11) or anti-human CD324 (E-Cadherin) antibody conjugated with PE (BioLegend; Clone 67A4). Unstained cells were used as negative control.

Approximately 10,000 gated events were acquired for each sample on a FACSCanto cytometer (Becton Dickinson, Franklin Lakes, NJ, USA). Flow cytometry data were analyzed using FlowJo software (v10; TreeStar, Ashland, OR, USA). Dead cells and debris were excluded on the basis of forward-scatter and side-scatter. N- and E-Cadherin expression was calculated as fold change: median fluorescence intensity (MFI) of stained sample normalized with respect to the MFI of unstained sample.

\subsection{Immunoblot Analysis}

The cells were harvested, washed in PBS, and solubilized in lysis buffer in the presence of phosphatase and protease inhibitors $(50 \mathrm{mM}$ Tris- $\mathrm{HCl} \mathrm{pH} 8,150 \mathrm{mM} \mathrm{NaCl}, 1 \%$ Igepal CA-630, $0.5 \%$ Na-Doc, $0.1 \%$ SDS, $1 \mathrm{mM} \mathrm{Na} \mathrm{VO}_{4}, 1 \mathrm{mM} \mathrm{NaF}, 2.5 \mathrm{mM}$ EDTA, $1 \mathrm{mM}$ PMSF, and $1 \times$ protease inhibitor cocktail). After incubation on ice for $30 \mathrm{~min}$., the lysates were centrifuged at $14,000 \times \mathrm{g}$ for $10 \mathrm{~min}$. at $4{ }^{\circ} \mathrm{C}$ and the supernatant fractions were used for Western blot analysis. Protein concentration was measured by Bradford reagent (Pierce, Milan, Italy) using bovine serum albumin as a standard. The protein extracts $(20 \mu \mathrm{g} / \mathrm{lane})$ were resolved on a $12 \%$ SDS-polyacrylamide gel and electro-blotted onto PVDF membranes (Millipore, Milan, Italy). After transferring proteins onto PVDF membranes, Amido Black 1X Staining Solution (Sigma-Aldrich \#A8181) was used to confirm equal protein loading in different lanes. Briefly, the membranes were covered with Amido Black and stain by gentle shaking for one minute at room temperature; after that, membranes were de-stained by placing in an aqueous solution containing $25 \%$ isopropanol and $10 \%$ acetic acid for 30 minutes at room temperature. The membranes were blocked in 5\% low-fat milk in TBST (50 mM Tris pH $7.5,0.9 \% \mathrm{NaCl}, 0.1 \%$ Tween 20) for $1 \mathrm{~h}$ at room temperature and probed overnight at $4{ }^{\circ} \mathrm{C}$ with a mouse polyclonal anti-p53 (1:2000) (Santa Cruz, \#sc-263), rabbit monoclonal anti-glyceraldehyde 3-phosphate dehydrogenase (GAPDH) (1:1000) (Cell Signaling, \#5174S) antibodies. Mouse monoclonal anti-vimentin (1:200) (Santa Cruz, \#sc-373717) was used to detect the expression levels of secreted vimentin in protein extracts that were derived from conditioned medium by a protein extraction method described in the next paragraph. Horseradish peroxidase conjugated anti-mouse or anti-rabbit IgGs (1:8000 in blocking solution) (Upstate Biotechnology, Milan, Italy) were used as secondary antibodies. Immunodetection was carried out using chemiluminescent substrates (Amersham Pharmacia Biotech, Milan, Italy) and recorded using a HyperfilmECL (Amersham Pharmacia Biotech). The ECL (Enhanced ChemiLuminescence) results were scanned and the amount of each protein band was quantified using NIH Image J software.

\subsection{Protein Extraction from Conditioned Medium (CM)}

The day after transient transfection, the AsPC-1 cells were washed six times in PBS (phosphate-buffered saline) and then incubated in serum-free RPMI for $22 \mathrm{~h}$. This serum-free time period of incubation has been chosen on the basis of our previous investigations in order to avoid cell injury. Cell viability, as determined with $0.4 \%$ trypan blue solution (Thermo Fischer Scientific), was higher than $95 \%$. The media containing secreted proteins were collected by centrifugation at $1000 \times g$ for $10 \mathrm{~min}$. to pellet floating cells and were defined as conditioned media (CM). After the addition of $1 \times$ protease inhibitor cocktail (Roche), $\mathrm{CM}$ were centrifuged again at $17,000 \times g$ for $20 \mathrm{~min}$. at $4{ }^{\circ} \mathrm{C}$ to pellet the remaining cell debris. The proteins in the $\mathrm{CM}$ were precipitated overnight at $-20{ }^{\circ} \mathrm{C}$ with 4 volumes of ice-cold acetone. The pellets were then collected by centrifugation at $17,000 \times g$ for $20 \mathrm{~min}$. at $4{ }^{\circ} \mathrm{C}$ and then resuspended in $100 \mathrm{mM}$ ammonium bicarbonate $\left(\mathrm{NH}_{4} \mathrm{HCO}_{3}\right)$. Protein concentrations were determined using BCA protein assay (Sigma). 


\subsection{In-Solution Digestion}

Before SWATH-MS analysis, the CM proteins were digested following the protocol provided by the manufacture (Applied Biosystem). Briefly, samples were prepared to have $100 \mu \mathrm{g}$ of protein in a final volume of $25 \mu \mathrm{L}$ of $100 \mathrm{mM} \mathrm{NH}_{4} \mathrm{HCO}_{3}$. The proteins were reduced using $2.5 \mu \mathrm{L}$ of dithiothreitol (200 mM DTT stock solution) (Sigma) at $90^{\circ} \mathrm{C}$ for $20 \mathrm{~min}$. and alkylated with $10 \mu \mathrm{L}$ of Cysteine Blocking Reagent (Iodoacetamide, IAM, $200 \mathrm{mM}$; Sigma) for $1 \mathrm{~h}$ at room temperature in the dark. DTT stock solution was then added to destroy the excess of IAM. After dilution with $300 \mu \mathrm{L}$ of water and $100 \mu \mathrm{L}$ of $\mathrm{NH}_{4} \mathrm{HCO}_{3}$ to raise $\mathrm{pH}, 5 \mu \mathrm{g}$ of trypsin (Promega, Sequence Grade) was added and digestion was performed overnight at $37^{\circ} \mathrm{C}$. Trypsin activity was stopped by adding $2 \mu \mathrm{L}$ of neat formic acid and the digests were dried by Speed Vacuum [21].

\subsection{Data Acquisition}

The digested samples were analyzed on a micro-LC Eksigent Technologies (Dublin, OH, USA) interfaced to a 5600+ TripleTOF mass spectrometer system (AB Sciex, Concord, ON, Canada) that was equipped with a DuoSpray Ion Source and a CDS (Calibrant Delivery System). The LC column was a Halo Fused C18 (AB Sciex, Concord, ON, Canada). The mobile phase was a mixture of $0.1 \%(v / v)$ formic acid in water (A) and $0.1 \%(v / v)$ formic acid in acetonitrile (B), eluting at a flow-rate of $15.0 \mu \mathrm{L} \mathrm{min.}{ }^{-1}$ at an increasing concentration of solvent B from $2 \%$ to $40 \%$ in $30 \mathrm{~min}$. The injection volume was $4.0 \mu \mathrm{L}$ and the oven temperature was set at $40{ }^{\circ} \mathrm{C}$. For identification purposes, the samples were subjected to data dependent analysis (DDA): the mass spectrometer operated using a mass range of 100-1500 Da (TOF scan with an accumulation time of $0.25 \mathrm{~s}$ ), followed by a MS/MS product ion scan from 200 to $1250 \mathrm{Da}$ (accumulation time of $5.0 \mathrm{~ms}$ ) with the abundance threshold set at $30 \mathrm{cps}$ ( 35 candidate ions can be monitored during every cycle). The ion source parameters in electrospray positive mode were set, as follows: curtain gas (N2) at 25 psig, nebulizer gas GAS1 at 25 psig, and GAS2 at 20 psig, ionspray floating voltage (ISFV) at $5000 \mathrm{~V}$, source temperature at $450^{\circ} \mathrm{C}$, and declustering potential at $25 \mathrm{~V}$. For the quantification, the samples were subjected to cyclic data independent analysis (DIA) of the mass spectra, using a 25-Da window: the mass spectrometer was operated, such that a 50-ms survey scan (TOF-MS) was performed and subsequent MS/MS experiments were performed on all precursors. These MS/MS experiments were performed in a cyclic manner while using an accumulation time of $40 \mathrm{~ms}$ per 25-Da swath (36 swaths in total) for a total cycle time of $1.5408 \mathrm{~s}$ [22]. The ions were fragmented for each MS/MS experiment in the collision cell while using the rolling collision energy. The MS data were acquired with Analyst TF 1.7 (AB SCIEX, Concord, ON, Canada). Two DDA and three DIA acquisitions were performed.

\subsection{Protein Database Search}

The DDA files were searched using Protein Pilot software v. 4.2 (AB SCIEX, Concord, ON, Canada) and Mascot v. 2.4 (Matrix Science Inc., Boston, MA, USA). The DIA files were converted to pseudo-MS/MS spectra with DIA-Umpire software and they were searched as DDA files [23,24]. Trypsin as digestion enzyme was specified for both the software. For Mascot we used two missed cleavages, the instrument was set to ESI-QUAD-TOF, and the following modifications were specified for the search: carbamidomethyl cysteins as fixed modification and oxidized methionine as variable modification. A search tolerance of 0.08 Da was specified for the peptide mass tolerance, and $10 \mathrm{ppm}$ for the MS/MS tolerance. The charges of the peptides to search for were set to $2+, 3+$, and $4+$, and the search was set on monoisotopic mass. The UniProt Swiss-Prot reviewed database containing human proteins (version 2015.07.07, containing 42131 sequence entries) was used and a target-decoy database search was performed. False Discovery Rate was fixed at $1 \%$. 


\subsection{Protein Quantification}

MS1 (precursor ion masses) and MS2 (fragment ion masses) chromatogram based quantitation was carried out in Skyline 3.1, an open source software project (http://proteome.gs.washington.edu/ software/skyline) [25]. Spectral libraries were generated in Skyline from database searches. All of the raw files acquired in DIA were directly imported into Skyline and MS1 precursor ions and MS/MS fragment ions were extracted for all peptides present in the MS/MS spectral libraries. Quantitative analysis was based on extracted ion chromatograms (XICs) for the top three resulting precursor ion peak areas e.g., $M, M+1$, and $M+2$ (MS1) and on XICs of up to three MS/MS fragment ions, typically $\mathrm{y}$ - and b-ions, matchingspecific peptides present in the spectral libraries. For statistical analysis of quantitative differences of proteins and peptides between samples, MSstats (v.2.0), an open-source R-based package [26], was used.

\subsection{Bioinformatics and Statistics Software}

The potential secretion pathways of regulated proteins were predicted with the SecretomeP 2.0 server (http://www.cbs.dtu.dk/services/SecretomeP/) for classical and non-classical secretion, while the localization of signal peptide cleavage sites were predicted with SignalP v.5.0 (http://www.cbs.dtu.dk/ services/SignalP/) [27].

The regulated proteins were analyzed using the STRING database (v.11.0) (http://string-db.org), which is a database of known and predicted protein-protein interactions [28]. The Cytoscape (v.3.7.2) ClueGO (v.2.5.4) plugin was used to visualize the enriched pathways associated with the Kyoto Encyclopaedia of Genes and Genome (KEGG) database [29]. In brief, KEGG pathways were explored with medium specificity and a kappa score of 0.4 . An enrichment/depletion method with a two-sided hypergeometric test was applied, correct with the Bonferroni step down for each p-value calculation. Enriched pathways with a $p$-value $<0.05$ were considered to be significant. Functional annotation of identified proteins was employed while using the Database for Annotation, Visualization, and Integrated Discovery (DAVID) (v.6.8) (http://david.abcc.ncifcrf.gov/) to identify gene ontology (GO) biological processes (BPs), molecular function (MFs), and cellular component (CCs). The BPs, MFs, and $\mathrm{CCs}$ that were enriched by the list of proteins were identified as the ones with $p$-value $<0.01$ calculated by DAVID [30].

\subsection{Statistical Analysis}

ANOVA analysis was performed by GraphPad Prism 5 software. $p$ value $<0.05$ was indicated as being statistically significant. Values are the means of three independent experiments $( \pm \mathrm{SD})$.

\section{Results}

\subsection{Cancer Cell Secretome Driven by mutant p53 Induces Hyper-Proliferative Effects}

We aimed to study the role of mutp53-driven secretome in cancer cell aggressiveness to investigate whether mutant p53 may influence the secretome of PDAC cells. We induced the exogenous expression of $\mathrm{R} 273 \mathrm{H}$ or $\mathrm{R} 175 \mathrm{H}$ mutp53 isoforms in p53-null AsPC-1 PDAC cells by using liposome-mediated transient transfection assay, as summarized in Figure 1A. Forty-eight hours later, we checked the effective over-expression of $\mathrm{p} 53$ in AsPC-1 by Western blotting and functionally analyzed the hyper-proliferative effect induced by mutant p53 isoforms, as compared to mock or wt-p53 (Figure 1B). Subsequently, AsPC-1 transfected cells were washed in PBS and then incubated in fresh culture medium for further $22 \mathrm{~h}$ to accumulate secreted proteins. This conditioned medium (CM) released by transfected AsPC-1 cells was transferred to new p53-null AsPC-1 cells, which were thus cultivated in wtp53- or mutp53-driven secretome for $48 \mathrm{~h}$ in order to study the functional effects of secretome driven by GOF R175H and R273H mutp53 isoforms. Figure 1C shows that both R175H and R273H p53 mutants are able to induce AsPC-1 cell hyper-proliferation through their mutp53-driven CM, as compared to their negative mock control or to wtp53-CM. Interestingly, in accordance with the tumor suppressor role of wild type p53, 
the wtp53-driven CM showed an inhibitory effect on cell growth. The absence of extracellular p53 in mutp53- or wtp53-driven CM was proved by Western blotting and then further confirmed by mass spectrometry analysis. Altogether, these data demonstrate that GOF mutant p53 isoforms can also exert their hyper-proliferative effects on cancer cells through the alteration of their secretome.


Figure 1. Cancer cell secretome driven by mutant p53 can induce hyper-proliferative effects. (A) A summary model of the approach used in this study: p53-null AsPC-1 cells were transfected with plasmids for $\mathrm{R} 273 \mathrm{H}$ or $\mathrm{R} 175 \mathrm{H}$ mutant $\mathrm{p} 53$ over-expression or its mock vector for $48 \mathrm{~h}$. Then, AsPC-1 transfected cells were washed in PBS to remove liposomes and incubated with fresh culture medium for further $22 \mathrm{~h}$ to accumulate secreted proteins. After that, the conditioned medium (CM) of AsPC-1 transfected cells was transferred to untransfected p53-null AsPC-1 cells. After 48 h, several biological phenomena listed in the figure were investigated in AsPC-1 cells bearing mutp53-driven CM. (B) Cell growth was measured by Cristal Violet assay in p53-null AsPC-1 cells transfected for over-expression of wtp53, R175H or R273H mutp53. Accompanying Western blotting of p53 and of GAPDH for control loading are reported. Statistical analysis * $p<0.05 \mathrm{R} 175 \mathrm{H}$ vs Mock; $\# p<0.05 \mathrm{R} 273 \mathrm{H}$ vs Mock; $\$ p<0.05$ wtp53 vs Mock. (C) Cell growth was measured by Cristal Violet assay in untransfected p53-null AsPC-1 cells cultivated with wtp53-, R175H- or R273H-CM. Accompanying Western blotting of p53 and amido black staining are reported. Statistical analysis * $p<0.05$ CM-R175H vs CM-Mock; \# $p<0.05$ CM-R273H vs CM-Mock; $\$ p<0.05$ wtp53 vs CM-Mock.

\subsection{Mutp53-Driven Secretome Mediates Anti-Apoptotic, Anti-Autophagic and Chemoresistance Effects}

We tested whether $\mathrm{CM}-\mathrm{R} 175 \mathrm{H}$ and $\mathrm{CM}-\mathrm{R} 273 \mathrm{H}$ were also able to induce other typical hallmarks induced by intracellular GOF mutant p53 isoforms, as the inhibition of cell death-related phenomena (i.e., apoptosis and autophagy) and the stimulation of chemoresistance to the standard drug gemcitabine to better investigate the effects of mutant p53 secretome. Figure 2A shows that mutp53-derived CM was able to counteract apoptosis in p53-null AsPC-1 cells, in accordance with the well-known antiapoptotic effect of intracellular mutant p53 isoforms [31], which indicated that mutant p53 is also able to counteract apoptosis by promoting the secretion of some molecules that discourages cell death. 


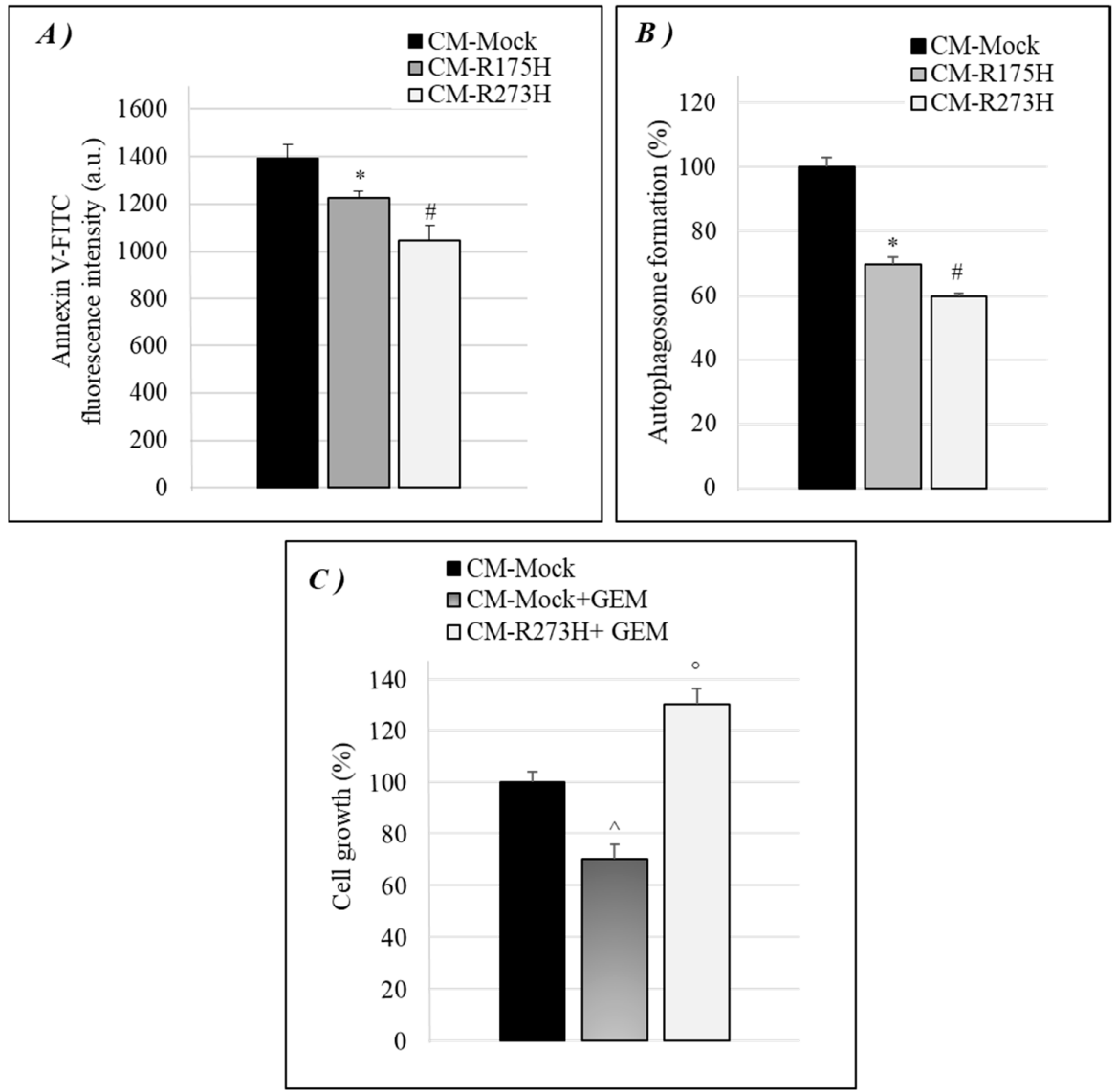

Figure 2. Mutp53-driven secretome mediates anti-apoptotic, anti-autophagic and chemoresistance effects. (A) Apoptosis was determined by the annexinV/FITC binding assay in AsPC-1 cultivated with mutp53-derived CM. The annexinV-FITC fluorescence intensity was measured by using a multimode plate reader and reported as arbitrary units (a.u.). (B) Autophagosome formation assay was determined by intracellular staining using the MDC probe in AsPC-1 cultivated with mutp53-derived CM. Statistical analysis * $p<0.05$ CM-R175H vs CM-Mock; \# $p<0.05$ CM-R273H vs CM-Mock. (C) Cell growth was analyzed by Cristal Violet assay in AsPC-1 cultivated with mutp53-derived CM treated with $1 \mu \mathrm{M}$ GEM for $48 \mathrm{~h}$. Statistical analysis ^ $p<0.05 \mathrm{CM}-\mathrm{R} 273 \mathrm{H}+\mathrm{GEM}$ vs CM-Mock + GEM; ${ }^{\circ} p<0.05 \mathrm{CM}-\mathrm{Mock}+$ GEM vs CM-Mock.

Moreover, since we previously demonstrated that GOF mutant p53 proteins blocked the autophagic flux by the regulation of some molecular pathways, as AMPK, AKT/mTOR, and some crucial autophagy-related genes (ATGs) [32,33], we wondered whether mutant p53 might also counteract autophagy by secretome alteration. Figure 2B shows that the CM released by R175H- or R273H-mutp53 AsPC-1 cancer cells decreases the amount of intracellular autophagic vesicles, when compared to p53-null driven CM.

Furthermore, our previous data showed that mutant p53 can stimulate the chemoresistance of PDAC cells to the drug gemcitabine (GEM) [11]. Thus, we investigated whether mutp53-driven secretome may also be able to reduce cancer cells sensitivity to GEM. Figure $2 \mathrm{C}$ shows that GEM inhibited cell growth of AsPC-1 cells that were cultivated with mock-derived CM, while the CM derived by $\mathrm{R} 273 \mathrm{H}$ mutant p53 AsPC-1 cells counteracted the therapeutic effect of GEM, as compared to its mock control, representing an important aspect to be further considered for clinical therapeutic studies. Overall, these data provide evidence that mutant p53 proteins influence the secretion of components that contribute to cancer cell growth and resist cell death-related phenomena, such as apoptosis, autophagy, and anticancer drug exposure. 


\subsection{Mutp53-Driven Secretome Stimulates Cancer Cell Migration and Epithelial-to-Mesenchymal Transition}

Because GOF mutant p53 isoforms can stimulate cancer cell migration, we also investigated whether mutp53-induced modulation of secretome can have a role in this phenomenon [17]. Using the same methodological approach described in Figure 1A, we discovered that CM-R175H and CM-R273H are able to favor the migration of AsPC-1 cells (Figure 3A). In particular, we observed a faster wound closure in p53-null ASPC-1 cells cultivated with R175H or R273H mutant p53-driven secretome, as compared to CM derived from their mock control (CM-mock). We also used stable clones of p53-null lung cancer H1299 cells non-expressing (mock) or constitutively expressing the R273H mutant p53 isoform, which were previously used as a valuable cell model to study the oncogenic effects of mutant p53, in order to further straighten these data [33]. As control of mutant p53 expression and functionality, in Figure S1 we report the cellular hyper-proliferative effect and the mutant p53 expression level observed in mock and R273H-mutp53 clones of H1299 cells. Concerning the migration assay, Figure 3B shows also that the secretome derived by $\mathrm{H} 1299$ cancer cells stably expressing $\mathrm{R} 273 \mathrm{H}$ mutant p53 (CM-H1299 R273H) induced cell migration of AsPC-1 p53-null cells as compared to mock control (CM-H1299 mock), further supporting the results on AsPC-1 secretome shown in Figure 3A.

Finally, we investigated whether GOF mutp53-driven secretome contributes to another typical feature that is induced by mutant p53, namely epithelial-to-mesenchymal transition (EMT) of cancer cells, which is a phenomenon strictly connected to cancer cell migration [34,35]. In Figure 3C, we show that $\mathrm{R} 175 \mathrm{H}$ mutant $\mathrm{p} 53$ increased $\mathrm{N}$-cadherin and decreased E-cadherin protein expression in cancer cell membrane, as compared to mock, thus markedly altering the N/E cadherin ratio, a typical feature of EMT. Intriguingly, CM-derived by AsPC-1 overexpressing $\mathrm{R} 175 \mathrm{H}$ mutant p53 is also able to induce the same regulation of $\mathrm{N}$ - and E-cadherin expression level in cancer cell membrane, as compared to CM-mock derived by AsPC-1 cells. Consequently, the N/E cadherin ratio was higher in AsPC-1 cells cultivated with CM-R175H as compared to the same cells that were cultivated with CM-mock. Since N-cadherin promotes motility, invasion, and produces a scattered phenotype with EMT, in association with a reduction in the expression of E-cadherin [36,37], our results suggest that proteins that are secreted by mutant p53-expressing cancer cells have a crucial role in EMT transition, thus sustaining the migration and aggressiveness of cancer cells.

\subsection{Identification of Secreted Proteins from Mutp53-Driven Secretome}

After the investigation of the oncogenic functions of mutp53-driven secretome, we aimed to identify the main differentially secreted proteins by mutant p53 isoforms in PDAC. Thus, we analyzed the protein composition of the CM released by AsPC-1 cells expressing GOF mutp53 as compared to p53-null AsPC-1 cells (mock). After the transfection period (48 h), the cells were washed to remove DNA:liposome complexes and they were cultured for a further 22 hours to accumulate secreted proteins in serum-free culture medium to avoid protein cross-contamination by serum. Notably, this serum-free culture period has been identified as the maximum time period without delay of cell growth or signals of cell death (Figure S2) to avoid undiscriminating cellular lysis. A peptide liquid chromatography separation followed by mass spectrometry analysis and database search with Protein Pilot and Mascot was then performed. SWATH-MS analyses were performed in triplicates for each analyzed sample and they were imported in the Skyline software to perform the label-free quantification and the identification of regulated proteins. We identified 194 proteins in CM-R273H and 228 proteins in CM-R175H transfected cells. The major part of them (165 proteins) were in common between the two mutp53-driven secretomes of AsPC-1 cells. The semi-quantitative proteomic analysis showed that 45 proteins resulted in being significantly modulated in the CM-R175H (Table S1) and 58 proteins were significantly modulated in CM-R273H (Table S2) as compared to the mock control (CM-mock). Further analyzing the modulated proteins, we identified 15 differentially secreted proteins in common between CM-R175H and CM-R273H (Table 1). Among these proteins that can better represent a common signature of secretome alteration driven by different GOF p53 mutant isoforms, there are several interesting proteins, such as growth factors (IGFBP1), histone proteins (HIST1H3A, HIST1H4A, 
HIST2H2AA3, HIST2H3A, and H2AFV), endothelial protein C receptor (EPCR), and others, which are commented in the Discussion section. We analyzed by western blotting the extracellular expression level of vimentin (VIM) in CM-mock, CM-R273H, and CM-R175H of AsPC-1 cells, confirming the hyper-secretion of VIM induced by both mutant p53 isoforms in order to validate mass spectrometry data (Figure S3). We have further investigated whether these 15 proteins were already identified in PDAC-derived exosomes and seven of them, namely PROCR, TIMP1, EZR, PSAP, VIM, CLSTN1 and CFL1, were detected in the proteome of pancreatic cancer exosomes using mass spectrometry [38], which suggests their roles as key signaling molecules.
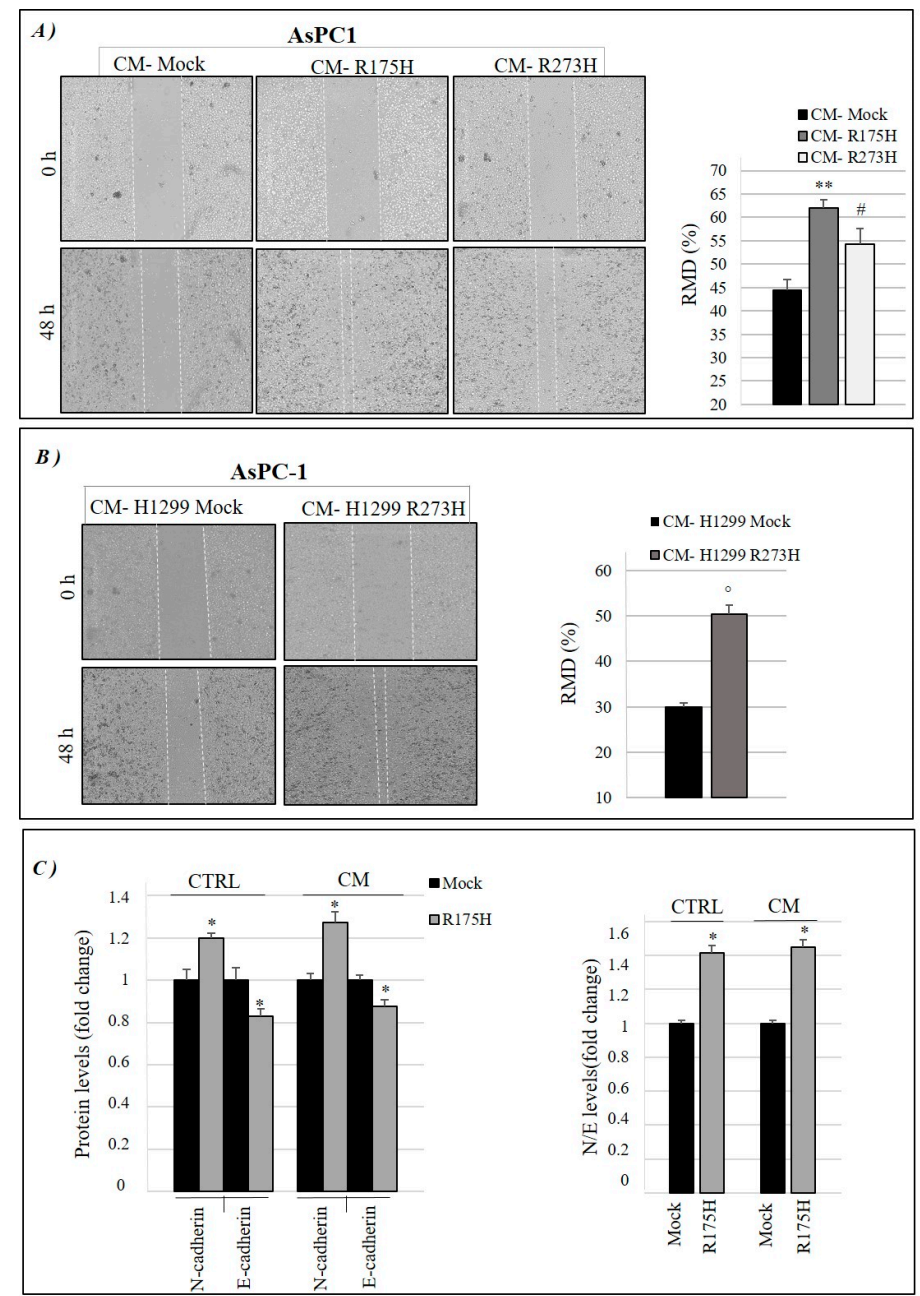

Figure 3. Mutp53-driven secretome stimulates cancer cell migration and epithelial-mesenchymal transition (EMT). (A) Wound closure cell assay on the confluent p53-null AsPC-1 cell monolayer that received mutp53-driven secretome from transiently transfected AsPC-1 cells or (B) from H1299 cells stably expressing mutant p53-R273H, as compared to its mock control. A scratch was performed in the cell monolayer at time zero, after that we monitored cell migration for $48 \mathrm{~h}$. The images were analyzed quantitatively by using ImageJ computing software. Migration ability expressed as relative migration distance (RMD) increased in cells cultured with mutp53-derived CM. Statistical analysis ** $p<0.01$ CM-R175H vs CM-Mock; \# $p<0.05$ CM-R273H vs CM-Mock; ${ }^{\circ} p<0.05$ CM-H1299 R273H vs Mock. (C) Quantification of N-cadherin and E-cadherin expression levels by FACS analysis in AsPC-1 cells transfected with mock or with plasmid for mutp53 R175H over-expression (CTRL) and in AsPC-1 cells bearing the conditioned medium from mock or mutp53 R175H-expressing AsPC-1 cells (CM) (left panel). We also calculated the expression level of N- to E-cadherin ratio (right panel). Statistical analysis * $p<0.05 \mathrm{R} 175 \mathrm{H}$ vs mock. 
Table 1. Fifteen common secreted proteins by both $\mathrm{R} 273 \mathrm{H}$ or $\mathrm{R} 175 \mathrm{H}$ mutant p53 isoforms expressed in AsPC-1 cells and identified by using high-resolution SWATH-MS technology $(p<0.05)$.

\begin{tabular}{|c|c|c|c|c|c|}
\hline \multirow[t]{2}{*}{ Accession Name } & \multirow[t]{2}{*}{ Entry } & \multirow[t]{2}{*}{ Protein Names } & \multirow[t]{2}{*}{ Gene } & \multicolumn{2}{|c|}{$\begin{array}{c}\text { Fold Change } \\
\text { versus Mock (FC) }\end{array}$} \\
\hline & & & & R273H & R175H \\
\hline IBP1_HUMAN & P08833 & $\begin{array}{l}\text { Insulin-like growth factor-binding } \\
\text { protein } 1\end{array}$ & IGFBP1 & 4.49 & 3.03 \\
\hline EPCR_HUMAN & Q9UNN8 & Endothelial protein $C$ receptor & PROCR & 2.42 & 1.49 \\
\hline TIMP1_HUMAN & P01033 & Metalloproteinase inhibitor 1 & TIMP1 & 2.18 & 1.30 \\
\hline DCD_HUMAN & P81605 & Dermcidin & DCD & 1.94 & 1.37 \\
\hline EZRI_HUMAN & P15311 & Ezrin & EZR & 1.82 & 2.48 \\
\hline SAP_HUMAN & P07602 & Prosaposin & PSAP & 1.64 & 1.42 \\
\hline VIME_HUMAN & P08670 & Vimentin & VIM & 1.47 & 2.32 \\
\hline CSTN1_HUMAN & O94985 & Calsyntenin-1 & CLSTN1 & 1.43 & 2.51 \\
\hline TAD2B_HUMAN & Q86TJ2 & Transcriptional adapter 2-beta & TADA2B & 1.39 & 1.37 \\
\hline COF1_HUMAN & P23528 & Cofilin-1 & CFL1 & 1.35 & 1.52 \\
\hline H4_HUMAN & P62805 & Histone $\mathrm{H} 4$ & HIST1H4A & 0.54 & 0.76 \\
\hline H31_HUMAN & P68431 & Histone H3.1 & HIST1H3A & 0.43 & 0.46 \\
\hline H32_HUMAN & Q71DI3 & Histone H3.2 & HIST2H3A & 0.41 & 0.40 \\
\hline H2AV_HUMAN & Q71UI9 & Histone H2A.V & H2AFV & 0.33 & 0.45 \\
\hline H2A2A_HUMAN & Q6FI13 & Histone $\mathrm{H} 2 \mathrm{~A}$ type $2-\mathrm{A}$ & HIST2H2AA3 & 0.32 & 0.45 \\
\hline
\end{tabular}

\subsection{Bioinformatic Analyses and Interaction Networks of Mutp53-Driven Secreted Proteins}

Proteins that were detected in secretome samples were analyzed with the SignalP 5.0 and SecretomeP 2.0 prediction algorithms in order to determine which proteins are predicted to be secreted via classical (signal peptide-directed) or non-classical secretion mechanisms. The SignalP software allowed for defining the species that are secreted through the classical endoplasmic reticulum (ER)/Golgi pathway: all of the proteins lacking the presence of the classical signal peptide for the translocation to the ER, were then tested by SecretomeP 2.0 software for the putative export through one of the so-called non-classical secretory pathways (Table S3). Out of the 194 proteins that were detected in $\mathrm{CM}-\mathrm{R} 273 \mathrm{H}$, secretory signal peptides were present in $42(22 \%)$ of these proteins (SignalP D score $>0.45$ ) and $33(17 \%)$ were identified as non-classically secreted proteins (SecretomeP NN score $>0.6$, with no secretory signal present). Of the 228 proteins that were detected in CM-R175H transfected cells, secretory signal peptides were present in $36(16 \%)$ (SignalP D score $>0.45)$ and $33(15 \%)$ were identified as non-classically secreted proteins (SecretomeP NN score $>0.6$, with no secretory signal present). Together, these predictions account for $\sim 55 \%$ and $~ 31 \%$ of the secreted proteins detected in CM of $\mathrm{R} 273 \mathrm{H}$ and of $\mathrm{R} 175 \mathrm{H}$ transfected AsPC-1 cells, respectively. Thus, these algorithms are not able to predict which subsets of proteins may be released from cells: in fact, proteins from various subcellular locations may be released by different mechanisms to play a biological role outside of the cell. This is also confirmed by the fact that, out of the 257 secreted proteins, $204(79 \%)$ have been previously identified in cancer secretomes (www.cancersecretome.org).

The functional annotation of enriched secreted proteins was examined using DAVID software by performing enrichment analysis of biological processes (BPs), molecular functions (MFs), and cellular components (CCs) (Figure 4A,B).

Interestingly, the most significantly enriched BPs categories included cell-cell adhesion $(22 \%$ of proteins), canonical glycolysis (9\%), glycosaminoglycan metabolic process (13\%) and extracellular matrix disassembly $(10 \%)$. Moreover, the DAVID software associated the secretome profile with some interesting molecular functions, such as glycoprotein binding $(10 \%)$ and insulin-like grow factor II binding (5\%). Finally, the enrichment analysis of CCs revealed that enriched secreted proteins were mainly localized into the extracellular exosome, i.e., vesicles released in the extracellular region ( $87 \%$ and $74 \%)$, as well as in the extracellular matrix (Table S4). 


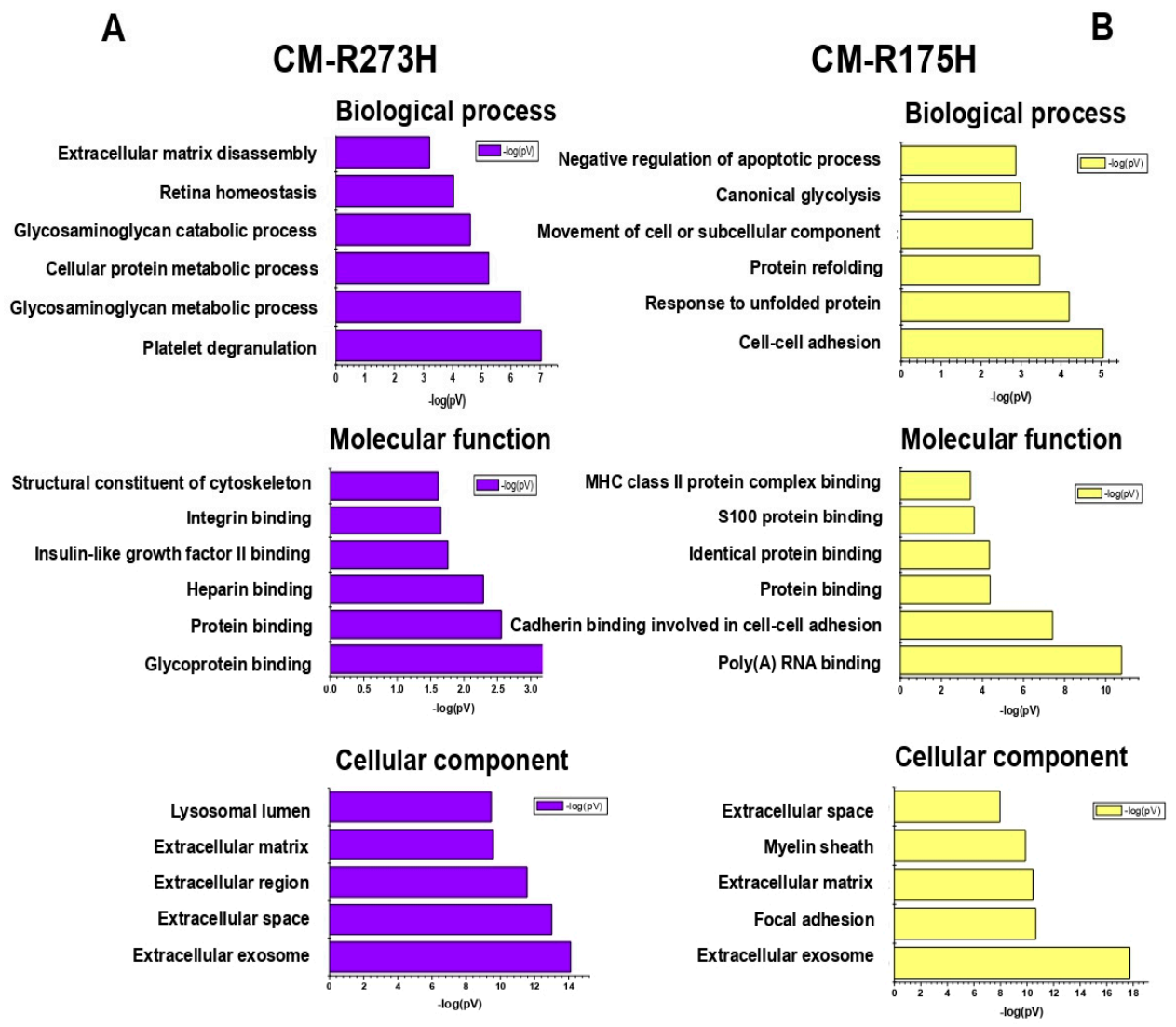

Figure 4. Bioinformatic analyses of enriched secreted proteins. Biological processes, molecular functions and cellular component of secreted proteins detected in (A) CM of R273H and in (B) $\mathrm{CM}$ of $\mathrm{R} 175 \mathrm{H}$ transfected AsPC-1 cells.

We have further explored the enriched pathways and functions that are associated with modulated proteins quantified in the secretome by using the ClueGO app for Cytoscape platform. Only significant pathways or terms were presented by setting the statistical threshold ( $p$-value $<0.05)$ and using the KEGG database as a reference. Figure 5 shows the functionally grouped networks of regulated proteins in the $\mathrm{CM}-\mathrm{R} 273 \mathrm{H}$ and $\mathrm{CM}-\mathrm{R} 175 \mathrm{H}$ samples. A blue term indicates an abundance increase when compared to the mock control, while a red term indicates an abundance decrease. Terms are linked based on $\mathrm{K}$-score $(\geq 0.4)$, edge thickness indicates the association strength while node size corresponds to the statistical significance for each term. The results show an over secretion of the endopeptidase inhibitor activity and the down-regulation of systemic lupus erythematosus related-proteins for CM-R273H. The analysis of CM-R175H sample reported an enrichment of proteins related to extracellular matrix (also present in CM-R273H) and an interesting enrichment of proteins that are involved in the glycolysis and gluconeogenesis, in agreement with the DAVID results.

STRING software was employed in order to investigate the functional and physical protein interactions among p53 and the differentially secreted proteins (Figure 6). Our analysis revealed that the following 11 proteins are clustered in a tight interaction network centered on p53: HMGA1, HIST1H1C, YWHAZ, YWHAG, HSP90AB1, HSPB1, HSP90AA1, HSPA8, PRDX1, TXN, and NPM1. Altogether these data allow for better understanding the complex network of proteins differentially secreted by mutant p53 and their relative functions and potential interactions. 

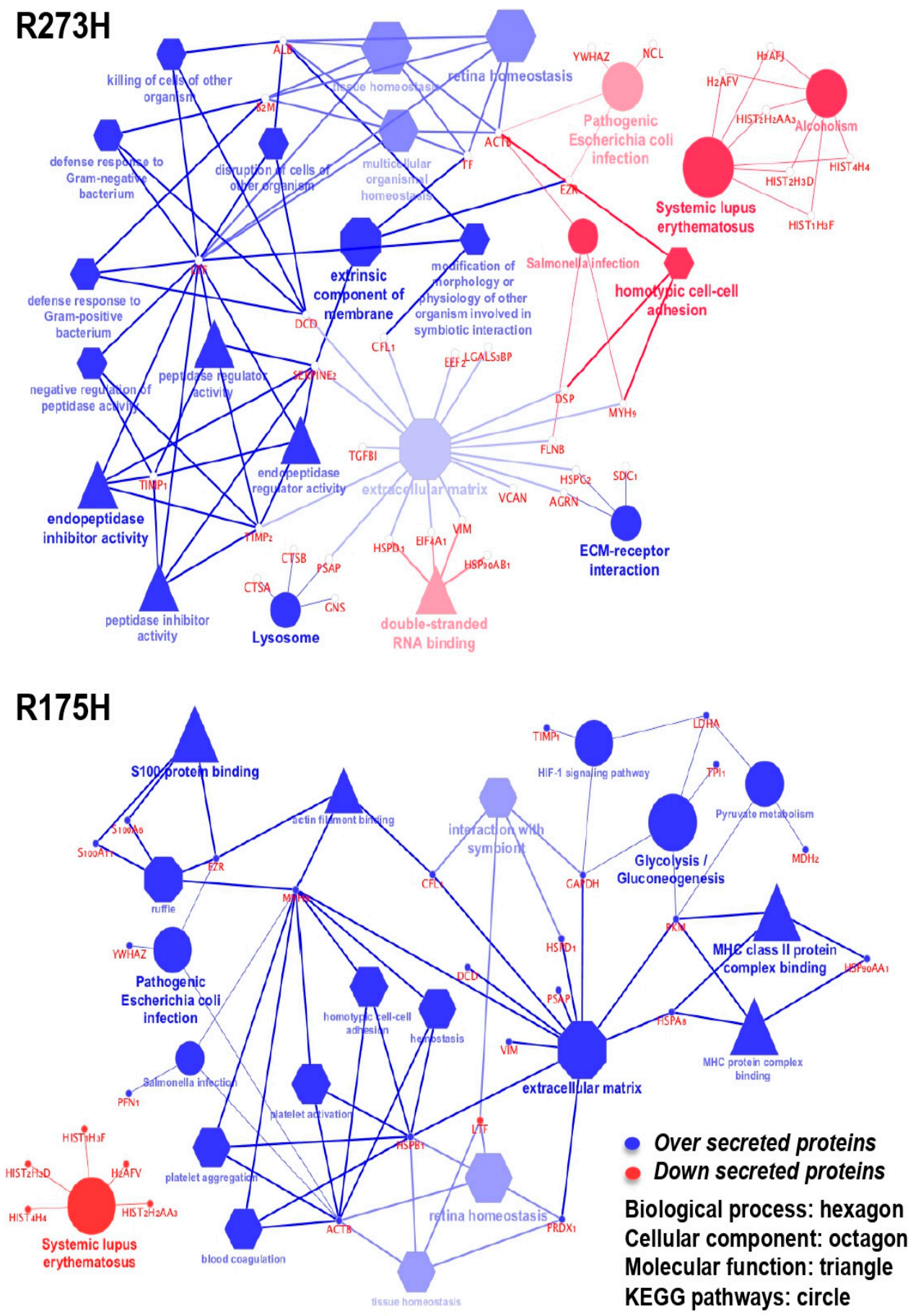

Figure 5. Cytoscape-based ClueGo/CluePedia pathway analysis and visualization. The enriched pathways were derived by the Kyoto Encyclopaedia of Genes and Genome (KEGG) database. The figure reports the functionally grouped networks of regulated proteins in the $\mathrm{R} 273 \mathrm{H}$ and $\mathrm{R} 175 \mathrm{H}$ transfected cell line. Blue term indicates an abundance increase compared to the mock control while red term indicates an abundance decrease. Terms are linked based on $\mathrm{K}$-score $(\geq 0.4)$, edge thickness indicates the association strength while node size corresponds to the statistical significance for each term. Biological processes are represented with hexagons, cellular components with octagons, molecular functions with triangles and KEEG pathways with circles. 


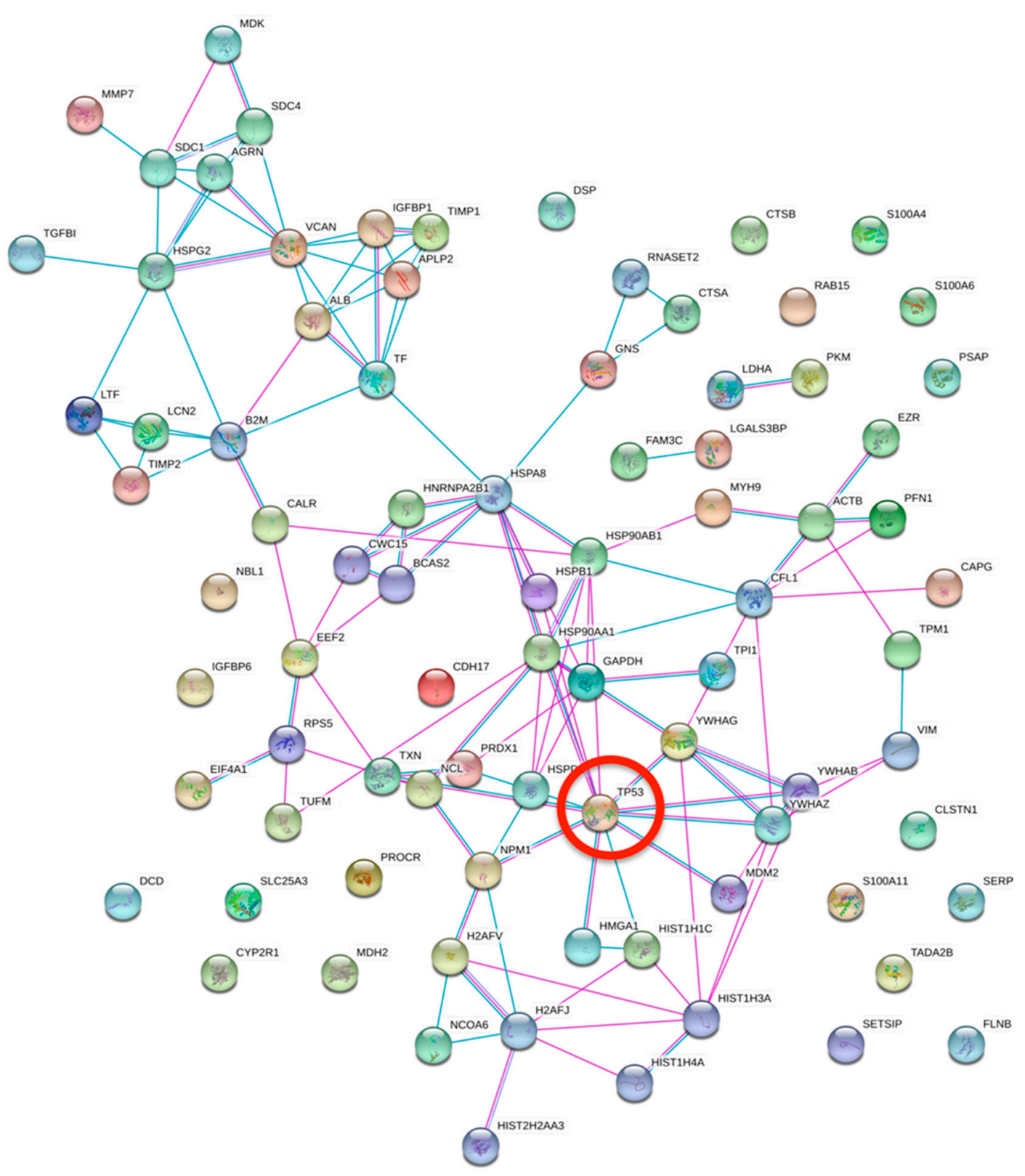

Figure 6. STRING analysis. Protein-protein interactions among modulated proteins secreted by both $\mathrm{R} 273 \mathrm{H}$ and $\mathrm{R} 175 \mathrm{H}$ transfected cells. TP53 was manually added to identify potentially related connections. Among the modulated proteins, 11 proteins are clustered in a tight interaction network centered on $\mathrm{p} 53$.

\section{Discussion}

The TP53 gene is one of the most frequently mutated genes in cancers, especially in PDAC, and most of its mutations are missense mutations in the DNA binding domain, resulting in the expression of mutant isoforms of p53, which acquire new oncogenic properties, referred to as gain-of-function (GOF) [9]. These novel functions are involved in a plethora of different cellular pathways that are focused on cancer progression and aggressiveness, counteracting apoptosis, autophagy, and cellular senescence, and promoting invasion, metastasis, and chemoresistance $[11,39,40]$. The influence of mutant p53 in the clinical outcome of cancer patients, the high frequency of GOF mutations in the TP53 gene, and the involvement of mutant p53 in a number of different cellular pathways have stressed the need to deeply investigate the events that are associated to cancer progression driven by 
mutant p53 isoforms in molecular oncology. Here, we discovered that the secretome driven by mutant p53 is able to favor cell growth and chemoresistance and counteract cell death-related mechanisms. Thus, we investigated the secreted proteins modulated by mutant p53 and identified a number of differentially secreted proteins by R175H (Supplementary Materials Table S1) or R273H (Supplementary Materials Table S2) mutant p53 isoforms. Interestingly, we identified 15 proteins (listed in Table 1) that were differentially secreted by both mutant p53 isoforms with the same trend of regulation. The clinical impact in cancers of these proteins and their involvement in the modulation of cancer microenvironment are discussed below.

Among mutp53-driven hyper-secreted proteins, we identified cofilin (COF1), which is involved in tumor cell migration and invasion by promoting actin cytoskeleton reorganization and cell-cell adhesion regulation and the level of cofilin-1 in patient's sera is associated with PDAC progression and poor prognosis [41-43]; calsyntenin-1 (CLSTN1), which plays a fundamental role in cellular adhesion and cell communication and its expression level was increased in sera of patients with lung adenocarcinoma or in ovarian adenocarcinoma cell lines, but the molecular mechanisms of CLSTN1 in cancer still need to be investigated [44-46]; vimentin (VIME), which is a well-known marker for epithelial-mesenchymal transition (EMT), and elevated levels of circulating vimentin were detected in hepatocellular carcinoma and in circulating tumor cells (CTCs) in PDAC. Notably, the presence of vimentin $^{+}$CTCs was negatively associated with progression-free survival [47-49]. We also found that both $\mathrm{R} 273 \mathrm{H}$ and $\mathrm{R} 175 \mathrm{H}$ p53 mutant isoforms favor the hyper-secretion of the tissue inhibitor matrix metalloproteinase 1 (TIMP1) in PDAC cells. Matrix metalloproteases (MMPs) are able to impact tumor cell behavior in vivo by several means: (i) the direct degradation of the stromal connective tissue and basement membrane components, favoring the invasion and metastasis of cancer cells [50]; (ii) cleavage of membrane-bound growth factors or cytokines as well as their receptors [51]; (iii) and, cleavage of cell adhesion molecules, such as cadherins, leading to an increased cell motility occurring in EMT [52]. On the other hand, the activity of MMPs is specifically inhibited by TIMPs, but it is now assumed that TIMPs are multifactorial proteins that are also involved in the induction of proliferation and inhibition of apoptosis [53]. Eirò et al. found that subgroups of tumors showing a stromal molecular profile of abundant MMPs and TIMPs expression are strongly associated with higher recurrence of distant metastases. On the contrary, tumors with stromal phenotypes displaying low molecular profiles have an excellent clinical outcome [54]. These are relevant findings when considering that MMPs are mainly governed by the tumor stroma and they exert powerful influences on the local tissue microenvironment during tumorigenesis and progression. In this context, we suggest that TIMP1 hypersecretion by tumor cells expressing mutant p53 might further contribute to render the tumor microenvironment prone to invasion or metastasis. Accordingly, TIMP1 is considered as a prognostic marker for cancer progression and metastasis [55,56]. An increase in TIMP1 gene expression and secretion has been shown in PDAC mouse models, as well as in human biopsies and serum [57]. The high serum concentration of TIMP1 is related to poor prognosis in ovarian cancer and in many other malignant tumors [57,58]. Our data also revealed a strong hyper-secretion of insulin-like growth factor-binding protein 1 (IGFBP1) in both R273H- and R175H-driven secretome samples. IGF signaling and p53 are strongly connected in cancer, especially in relation to tumor development and progression [59]. IGFBP1 is also involved in the activation of O-GlcNAcylation of FoxO1 in pancreatic $\beta$ cells by promoting AKT inhibition [60] in cancer cell response to DNA damage [61] and it promotes angiogenesis in glioblastoma [62]. Furthermore, high levels of serum IGFBP-1 were shown in patients with nasopharyngeal carcinoma (NPC) and associated with poor prognosis [63]. In the secretome of both p53 mutants, we have also observed the hyper-secretion of the endothelial protein $C$ receptor (PROCR), which is implicated in the carcinogenesis of various tumor types [64]. Indeed, PROCR has a tumor promoting effect and its silencing in gastric cancer inhibits the proliferation and migration via the ERK1/2 pathway, while, in ovarian cancer cells, it induces cell migration via MEK-ERK and Rho-GTPase pathways [65]. Interestingly, Wang et al. reported that IGF-1 receptor mediates the signaling function of PROCR in breast cancer cells [66]. In particular, they demonstrated that PROCR induces the activation of 
ERK and PI3K-AKT-mTOR signal through the transactivation of IGF-1R by Src and concomitantly stimulates RhoA-ROCK-p38 signals. In our system, we can hypothesize that the mutp53-dependent secretion of both IGFBP1 and PROCR might act in synergy to trigger intracellular pathways that are involved in cancer cell proliferation. Previous studies have suggested that $\mathrm{PROCR}^{+}$cells have increased EMT features [67]. In our study, we observed that mutp53-dependent secretome increased the N/E cadherin ratio, which suggests the stimulation of EMT. Thus, PROCR might be another channel through which mutp53-dependent secretome promotes EMT and tumor progression. By a clinical perspective, PROCR can be considered to be a possible biomarker of cancer onset, since its secretion is related to enhanced cell survival, invasion, and immune down regulation in patients with ovarian cancer [68]. Dermcidin (DCD), ezrin (EZR), and prosaposin (PSAP) are also hyper-secreted in both R273H- and R175H-driven secretome samples and they promote cancer progression [69-71]. Elevated levels of DCD are associated with the early progression of breast cancer and metastatic progression of melanoma [72,73]. EZR promotes the invasion and metastasis of pancreatic cancer cells. It might provide a predictive and diagnostic signature in PDAC, but the mechanisms of ezrin-mediated tumor development still require further elucidation [70,74]. PSAP is a conserved glycoprotein with multiple functions and it is involved in the development of cancers [71,75]. In particular, in breast cancer, mesenchymal stem cells induces prosaposin secretion to drive the proliferation [76]. Furthermore, the serum-PSAP levels are increased in patients with advanced prostate cancer and this could provide a cell survival response after therapeutic interventions [77].

Our study also revealed hypo-secretion of five types of histones in both mutant R273H- and R175H-driven secretome samples. Besides nuclear functions, histones can act as endogenous danger signals when they shift from the nucleus to the extranuclear space [78]. Indeed, in response to apoptotic signals, histones translocate from genomic DNA to cytoplasm and they are then released in the extracellular compartment [79]. Thus, our data suggest that the reduced secretion of histones in mutp53-driven secretome samples might suggest one of several ways by which mutp53-driven secretome inhibits cell death-related phenomena, such as apoptosis, in accordance with the antiapoptotic role of intracellular mutant p53 isoforms [31].

\section{Conclusions}

Finally, these data show the key role of the TP53 gene in the network of the differentially secreted proteins. We finally provide evidence that, in addition to the alteration of gene expression profile or to the specific protein-protein intracellular interactions, the oncogenic role of mutant p53 can also be due to a marked alteration of cancer secretome that can promote cancer aggressiveness in an autocrine/paracrine manner and regulate the cancer-stroma relationship. Future investigations are needed to further discover the role and biological impact in cancer microenvironment of the specific proteins that are differentially secreted by mutant p53 and identified in the present study. Furthermore, we will also aim to investigate whether some of these differentially secreted proteins may constitute a secreted signature detectable in PDAC patients' sera that can be easily predictive for GOF TP53 gene mutations in cancer patients. This might also enable the identification of targeted therapies that are specifically addressed to inhibit growth of PDACs carrying oncogenic mutant p53, which are strongly resistant to traditional chemotherapies.

Supplementary Materials: The following are available online at http://www.mdpi.com/2218-273X/10/6/884/s1, Figure S1: p53 expression and functionality; Figure S2: Cell growth control both with and without fetal bovine serum; Figure S3: Secreted vimentin expression; Table S1: Secreted proteins by R175H-mutp53; Table S2: Secreted proteins by R273H-mutp53; Table S3: Analysis of secreted proteins by SignalP, SecretomeP software and in cancer secretome database; Table S4: Bioinformatic analyses of secreted proteins by DAVID software.

Author Contributions: Conceptualization and Project administration, G.B. and M.D.; Supervision, M.D., Methodology, G.B., J.B., M.M., C.C.; Funding acquisition, M.D., M.M. and A.S.; Resources, M.D., M.M., R.T.L., D.C., E.M., M.T.S.; writing—original draft preparation, G.B., M.D., M.M.; writing-review and editing, all co-authors. All authors have read and agreed to the published version of the manuscript. 
Funding: This research was funded by Ministero dell'Istruzione, dell'Università e della Ricerca (MIUR); by University of Verona (Joint Project 2015); by University of Piemonte Orientale (AGING Project) and by Associazione Italiana per la Ricerca sul Cancro (AIRC 5x1000 n. 12182).

Acknowledgments: We acknowledge the "Technological Platforms Center" (CPT) of the University of Verona for the biotechnological support to this study. We thank Samuele Cheri and Giulio Innamorati, University of Verona, for the technical support for cell migration assay performed with EVOS, and the Cell Sorting Platform of the Applied Research on Cancer (ARC-Net) Centre, University of Verona, Italy.

Conflicts of Interest: The authors declare no conflict of interest.

\section{References}

1. Adamska, A.; Domenichini, A.; Falasca, M. Pancreatic ductal adenocarcinoma: Current and evolving therapies. Int. J. Mol. Sci. 2017, 18, 1338. [CrossRef]

2. Bond-Smith, G.; Banga, N.; Hammond, T.M.; Imber, C.J. Pancreatic adenocarcinoma. BMJ 2012, 344 , e2476. [CrossRef] [PubMed]

3. Adamska, A.; Elaskalani, O.; Emmanouilidi, A.; Kim, M.; Razak, N.B.A.; Metharom, P.; Falasca, M. Molecular and cellular mechanisms of chemoresistance in pancreatic cancer. Adv. Boil. Regul. 2018, 68, 77-87. [CrossRef] [PubMed]

4. Amrutkar, M.; Gladhaug, I.P. Pancreatic cancer chemoresistance to gemcitabine. Cancers 2017, 9, 157. [CrossRef] [PubMed]

5. Kruse, J.-P.; Gu, W. Modes of p53 regulation. Cell 2009, 137, 609-622. [CrossRef]

6. Cho, S.-Y.; Park, C.; Na, D.; Han, J.Y.; Lee, J.; Park, O.-K.; Zhang, C.; Sung, C.O.; Moon, H.E.; Kim, Y.; et al. High prevalence of TP53 mutations is associated with poor survival and an EMT signature in gliosarcoma patients. Exp. Mol. Med. 2017, 49, e317. [CrossRef]

7. Waddell, N.; Initiative, A.P.C.G.; Pajic, M.; Patch, A.-M.; Chang, D.; Kassahn, K.; Bailey, P.; Johns, A.L.; Miller, D.K.; Nones, K.; et al. Whole genomes redefine the mutational landscape of pancreatic cancer. Nature 2015, 518, 495-501. [CrossRef]

8. Perri, F.; Pisconti, S.; Scarpati, G.D.V. P53 mutations and cancer: A tight linkage. Ann. Transl. Med. 2016, 4, 522. [CrossRef]

9. Freed-Pastor, W.; Prives, C. Mutant p53: One name, many proteins. Genes Dev. 2012, 26, 1268-1286. [CrossRef]

10. Pfister, N.T.; Prives, C. Transcriptional Regulation by Wild-Type and Cancer-Related Mutant Forms of p53. Cold Spring Harb. Perspect. Med. 2016, 7, a026054. [CrossRef]

11. Fiorini, C.; Cordani, M.; Padroni, C.; Blandino, G.; Di Agostino, S.; Donadelli, M. Mutant p53 stimulates chemoresistance of pancreatic adenocarcinoma cells to gemcitabine. Biochim. et Biophys. Acta (BBA) Bioenerg. 2015, 1853, 89-100. [CrossRef] [PubMed]

12. Butera, G.; Pacchiana, R.; Mullappilly, N.; Margiotta, M.; Bruno, S.; Conti, P.; Riganti, C.; Donadelli, M. Mutant p53 prevents GAPDH nuclear translocation in pancreatic cancer cells favoring glycolysis and 2-deoxyglucose sensitivity. Biochim. et Biophys. Acta (BBA) Bioenerg. 2018, 1865, 1914-1923. [CrossRef] [PubMed]

13. Cordani, M.; Butera, G.; Dando, I.; Torrens-Mas, M.; Butturini, E.; Pacchiana, R.; Oppici, E.; Cavallini, C.; Gasperini, S.; Tamassia, N.; et al. Mutant p53 blocks SESN1/AMPK/PGC-1 $\alpha / \mathrm{UCP} 2$ axis increasing mitochondrial O2- $\bullet$ production in cancer cells. Br. J. Cancer 2018, 119, 994-1008. [CrossRef] [PubMed]

14. Hanel, W.; Moll, U.M. Links between mutant p53 and genomic instability. J. Cell. Biochem. 2012, 113, $433-439$. [CrossRef]

15. Li, D.; Marchenko, N.D.; Schulz, R.; Fischer, V.; Velasco-Hernández, T.; Talos, F.; Moll, U.M. Functional inactivation of endogenous MDM2 and CHIP by HSP90 causes aberrant stabilization of mutant p53 in human cancer cells. Mol. Cancer Res. 2011, 9, 577-588. [CrossRef]

16. Pavlakis, E.; Stiewe, T. p53's extended reach: The mutant p53 secretome. Biomolology 2020, 10, 307. [CrossRef]

17. Cordani, M.; Pacchiana, R.; Butera, G.; D’Orazi, G.; Scarpa, A.; Donadelli, M. Mutant p53 proteins alter cancer cell secretome and tumour microenvironment: Involvement in cancer invasion and metastasis. Cancer Lett. 2016, 376, 303-309. [CrossRef] 
18. Chenau, J.; Michelland, S.; De Fraipont, F.; Josserand, V.; Coll, J.-L.; Favrot, M.-C.; Seve, M. The Cell Line Secretome, a Suitable Tool for Investigating Proteins Releasedin Vivoby Tumors: Application to the Study of p53-Modulated Proteins Secreted in Lung Cancer Cells. J. Proteome Res. 2009, 8, 4579-4591. [CrossRef]

19. Butera, G.; Pacchiana, R.; Donadelli, M. Autocrine mechanisms of cancer chemoresistance. Semin. Cell Dev. Boil. 2018, 78, 3-12. [CrossRef]

20. Da Cunha, B.R.; Domingos, C.; Stefanini, A.C.B.; Henrique, T.; Polachini, G.M.; Castelo-Branco, P.; Tajara, E.H. Cellular Interactions in the Tumor Microenvironment: The Role of Secretome. J. Cancer 2019, 10, 4574-4587. [CrossRef]

21. Brandi, J.; Manfredi, M.; Speziali, G.; Gosetti, F.; Marengo, E.; Cecconi, D. Proteomic approaches to decipher cancer cell secretome. Semin. Cell Dev. Boil. 2018, 78, 93-101. [CrossRef] [PubMed]

22. Pozza, E.D.; Manfredi, M.; Brandi, J.; Buzzi, A.; Conte, E.; Pacchiana, R.; Cecconi, D.; Marengo, E.; Donadelli, M. Trichostatin A alters cytoskeleton and energy metabolism of pancreatic adenocarcinoma cells: An in depth proteomic study. J. Cell. Biochem. 2017, 119, 2696-2707. [CrossRef] [PubMed]

23. Tsou, C.-C.; Avtonomov, D.M.; Larsen, B.; Tucholska, M.; Choi, H.; Gingras, A.-C.; Nesvizhskii, A.I. DIA-Umpire: Comprehensive computational framework for data-independent acquisition proteomics. Nat. Methods 2015, 12, 258-264. [CrossRef] [PubMed]

24. Tsou, C.-C.; Tsai, C.-F.; Teo, G.C.; Chen, Y.-J.; Nesvizhskii, A.I. Untargeted, spectral library-free analysis of data-independent acquisition proteomics data generated using Orbitrap mass spectrometers. Proteomics 2016, 16, 2257-2271. [CrossRef]

25. MacLean, B.; Tomazela, D.M.; Shulman, N.; Chambers, M.; Finney, G.L.; Frewen, B.; Kern, R.; Tabb, D.L.; Liebler, D.C.; MacCoss, M.J. Skyline: An open source document editor for creating and analyzing targeted proteomics experiments. Bioinformatics 2010, 26, 966-968. [CrossRef] [PubMed]

26. Choi, M.; Chang, C.-Y.; Clough, T.; Broudy, D.; Killeen, T.; MacLean, B.; Vitek, O. MSstats: An R package for statistical analysis of quantitative mass spectrometry-based proteomic experiments. Bioinformatics 2014, 30, 2524-2526. [CrossRef]

27. Manfredi, M.; Martinotti, S.; Gosetti, F.; Ranzato, E.; Marengo, E. The secretome signature of malignant mesothelioma cell lines. J. Proteom. 2016, 145, 3-10. [CrossRef]

28. Szklarczyk, D.; Gable, A.L.; Lyon, D.; Junge, A.; Wyder, S.; Huerta-Cepas, J.; Simonovic, M.; Doncheva, N.T.; Morris, J.H.; Bork, P.; et al. STRING v11: Protein-protein association networks with increased coverage, supporting functional discovery in genome-wide experimental datasets. Nucleic Acids Res. 2018, 47, D607-D613. [CrossRef] [PubMed]

29. Bindea, G.; Mlecnik, B.; Hackl, H.; Charoentong, P.; Tosolini, M.; Kirilovsky, A.; Fridman, W.H.; Pagès, F.; Trajanoski, Z.; Galon, J. ClueGO: A Cytoscape plug-in to decipher functionally grouped gene ontology and pathway annotation networks. Bioinformatics 2009, 25, 1091-1093. [CrossRef] [PubMed]

30. Dennis, G.; Sherman, B.T.; Hosack, D.A.; Yang, J.; Gao, W.; Lane, H.C.; Lempicki, R.A. DAVID: Database for Annotation, Visualization, and Integrated Discovery. Genome Biol. 2003, 4, P3. [CrossRef] [PubMed]

31. Kim, T.-H.; Lee, S.Y.; Rho, J.H.; Jeong, N.Y.; Soung, Y.H.; Jo, W.S.; Kang, D.-Y.; Kim, S.-H.; Yoo, Y.H. Mutant p53 (G199V) Gains Antiapoptotic Function through Signal Transducer and Activator of Transcription 3 in Anaplastic Thyroid Cancer Cells. Mol. Cancer Res. 2009, 7, 1645-1654. [CrossRef] [PubMed]

32. Cordani, M.; Butera, G.; Pacchiana, R.; Donadelli, M. Molecular interplay between mutant p53 proteins and autophagy in cancer cells. Biochim. et Biophys. Acta (BBA) Bioenerg. 2017, 1867, 19-28. [CrossRef] [PubMed]

33. Cordani, M.; Oppici, E.; Dando, I.; Butturini, E.; Pozza, E.D.; Nadal-Serrano, M.; Oliver, J.; Roca, P.; Mariotto, S.; Cellini, B.; et al. Mutant p53 proteins counteract autophagic mechanism sensitizing cancer cells to mTOR inhibition. Mol. Oncol. 2016, 10, 1008-1029. [CrossRef] [PubMed]

34. Lamouille, S.; Xu, J.; Derynck, R. Molecular mechanisms of epithelial-mesenchymal transition. Nat. Rev. Mol. Cell Boil. 2014, 15, 178-196. [CrossRef]

35. Lenfert, E.; Maenz, C.; Heinlein, C.; Jannasch, K.; Schumacher, U.; Pantel, K.; Tolstonog, G.V.; Deppert, W.; Wegwitz, F. Mutant p53 promotes epithelial-mesenchymal plasticity and enhances metastasis in mammary carcinomas of WAP-T mice. Int. J. Cancer 2014, 136, E521-E533. [CrossRef]

36. Gheldof, A.; Berx, G. Cadherins and Epithelial-to-Mesenchymal Transition. In Progress in Molecular Biology and Translational Science; Elsevier BV: Amsterdam, The Netherlands, 2013; Volume 116, pp. 317-336. 
37. Islam, S.; Carey, T.E.; Wolf, G.T.; Wheelock, M.J.; Johnson, K.R. Expression of N-cadherin by human squamous carcinoma cells induces a scattered fibroblastic phenotype with disrupted cell-cell adhesion. J. Cell Boil. 1996, 135, 1643-1654. [CrossRef]

38. Han, S.; Huo, Z.; Nguyen, K.; Zhu, F.; Underwood, P.W.; Basso, K.B.; George, T.J.; Hughes, S.J. The Proteome of Pancreatic Cancer-Derived Exosomes Reveals Signatures Rich in Key Signaling Pathways. Proteomics 2019, 19, 1800394. [CrossRef]

39. Aschauer, L.; Muller, P.A. Novel targets and interaction partners of mutant p53 Gain-Of-Function. Biochem. Soc. Trans. 2016, 44, 460-466. [CrossRef]

40. Muller, P.A.; Vousden, K.H. p53 mutations in cancer. Nat. Cell Biol. 2013, 15, 2-8. [CrossRef]

41. Mousavi, S.; Safaralizadeh, R.; Hosseinpour-Feizi, M.; Azimzadeh-Isfanjani, A.; Hashemzadeh, S. Study of cofilin 1 gene expression in colorectal cancer. J. Gastrointest. Oncol. 2018, 9, 791-796. [CrossRef]

42. Sousa-Squiavinato, A.C.M.; Rocha, M.R.; Barcellos-De-Souza, P.; De Souza, W.F.; Morgado-Diaz, J. Cofilin-1 signaling mediates epithelial-mesenchymal transition by promoting actin cytoskeleton reorganization and cell-cell adhesion regulation in colorectal cancer cells. Biochim. et Biophys. Acta (BBA) Bioenerg. 2019, 1866, 418-429. [CrossRef] [PubMed]

43. Satoh, M.; Takano, S.; Sogawa, K.; Noda, K.; Yoshitomi, H.; Ishibashi, M.; Mogushi, K.; Takizawa, H.; Otsuka, M.; Shimizu, H.; et al. Immune-complex level of cofilin-1 in sera is associated with cancer progression and poor prognosis in pancreatic cancer. Cancer Sci. 2017, 108, 795-803. [CrossRef] [PubMed]

44. Faça, V.M.; Ventura, A.P.; FitzGibbon, M.P.; Pereira-Faça, S.R.; Pitteri, S.J.; Green, A.E.; Ireton, R.C.; Zhang, Q.; Wang, H.; O'Briant, K.C.; et al. Proteomic Analysis of Ovarian Cancer Cells Reveals Dynamic Processes of Protein Secretion and Shedding of Extra-Cellular Domains. PLoS ONE 2008, 3, e2425. [CrossRef] [PubMed]

45. Chu, Y.; Lai, Y.-H.; Lee, M.-C.; Yeh, Y.-J.; Wu, Y.-K.; Tsao, W.; Huang, C.-Y.; Wu, S. Calsyntenin-1, clusterin and neutrophil gelatinase-associated lipocalin are candidate serological biomarkers for lung adenocarcinoma. Oncotarget 2017, 8, 107964-107976. [CrossRef] [PubMed]

46. Zhong, L.; Roybal, J.; Chaerkady, R.; Zhang, W.; Choi, K.; Alvarez, C.A.; Tran, H.; Yan, S.; Strieter, R.M.; Pandey, A.; et al. Identification of Secreted Proteins that Mediate Cell-Cell Interactions in an In Vitro Model of the Lung Cancer Microenvironment. Cancer Res. 2008, 68, 7237-7245. [CrossRef]

47. Satelli, A.; Li, S. Vimentin in cancer and its potential as a molecular target for cancer therapy. Cell. Mol. Life Sci. 2011, 68, 3033-3046. [CrossRef]

48. Sun, S.; Poon, R.T.P.; Lee, N.P.; Yeung, C.; Chan, K.L.; Ng, I.O.-L.; Day, P.J.R.; Luk, J. Proteomics of Hepatocellular Carcinoma: Serum Vimentin As a Surrogate Marker for Small Tumors $(\leq 2 \mathrm{~cm})$. J. Proteome Res. 2010, 9, 1923-1930. [CrossRef]

49. Wei, T.; Zhang, X.; Zhang, Q.; Yang, J.; Chen, Q.; Wang, J.; Li, X.; Chen, J.; Ma, T.; Li, G.; et al. Vimentin-positive circulating tumor cells as a biomarker for diagnosis and treatment monitoring in patients with pancreatic cancer. Cancer Lett. 2019, 452, 237-243. [CrossRef]

50. Nelson, A.R.; Fingleton, B.; Rothenberg, M.L.; Matrisian, L.M. Matrix metalloproteinases: Biologic activity and clinical implications. J. Clin. Oncol. 2000, 18, 1135. [CrossRef]

51. Egeblad, M.; Werb, Z. New functions for the matrix metalloproteinases in cancer progression. Nat. Rev. Cancer 2002, 2, 161-174. [CrossRef]

52. Roy, R.; Yang, J.; Moses, M.A. Matrix metalloproteinases as novel biomarkers and potential therapeutic targets in human cancer. J. Clin. Oncol. 2009, 27, 5287-5297. [CrossRef] [PubMed]

53. Jiang, Y.; Goldberg, I.D.; Shi, Y.E. Complex roles of tissue inhibitors of metalloproteinases in cancer. Oncogene 2002, 21, 2245-2252. [CrossRef] [PubMed]

54. Eiro, N.; Fernández-García, B.; Vazquez, J.; Del Casar, J.M.; Gonzalez, L.O.; Vizoso, F.J. A phenotype from tumor stroma based on the expression of metalloproteases and their inhibitors, associated with prognosis in breast cancer. OncoImmunology 2015, 4, e992222. [CrossRef] [PubMed]

55. Song, G.; Xu, S.; Zhang, H.; Wang, Y.; Xiao, C.; Jiang, T.; Wu, L.; Zhang, T.; Sun, X.; Zhong, L.; et al. TIMP1 is a prognostic marker for the progression and metastasis of colon cancer through FAK-PI3K/AKT and MAPK pathway. J. Exp. Clin. Cancer Res. 2016, 35, 148. [CrossRef] [PubMed]

56. Botta, G.P.; Reichert, M.; Reginato, M.J.; Heeg, S.; Rustgi, A.K.; Lelkes, P.I. ERK2-regulated TIMP1 Induces Hyperproliferation of K-RasG12D-Transformed Pancreatic Ductal Cells. Neoplasia 2013, 15, 359-372. [CrossRef] 
57. Prokopchuk, O.; Grünwald, B.; Nitsche, U.; Jäger, C.; Prokopchuk, O.L.; Schubert, E.C.; Friess, H.; Martignoni, M.E.; Krüger, A. Elevated systemic levels of the matrix metalloproteinase inhibitor TIMP-1 correlate with clinical markers of cachexia in patients with chronic pancreatitis and pancreatic cancer. BMC Cancer 2018, 18, 128. [CrossRef]

58. Rauvala, M.; Puistola, U.; Turpeenniemihujanen, T. Gelatinases and their tissue inhibitors in ovarian tumors; TIMP-1 is a predictive as well as a prognostic factor. Gynecol. Oncol. 2005, 99, 656-663. [CrossRef]

59. Conover, C.A. The IGF-p53 connection in cancer. Growth Horm. IGF Res. 2018, 39, 25-28. [CrossRef]

60. Fardini, Y.; Masson, E.; Boudah, O.; Ben Jouira, R.; Cosson, C.; Pierre-Eugene, C.; Kuo, M.; Issad, T. O-GlcNAcylation of FoxO1 in pancreatic $\beta$ cells promotes Akt inhibition through an IGFBP1-mediated autocrine mechanism. FASEB J. 2013, 28, 1010-1021. [CrossRef]

61. Chua, M.W.Y.; Lin, M.Z.; Martin, J.L.; Baxter, R.C. Involvement of the insulin-like growth factor binding proteins in the cancer cell response to DNA damage. J. Cell Commun. Signal. 2015, 9, 167-176. [CrossRef]

62. Nijaguna, M.B.; Patil, V.; Urbach, S.; Shwetha, S.D.; Sravani, K.; Hegde, A.S.; Chandramouli, B.A.; Arivazhagan, A.; Marin, P.; Santosh, V.; et al. Glioblastoma-derived Macrophage Colony-stimulating Factor (MCSF) Induces Microglial Release of Insulin-like Growth Factor-binding Protein 1 (IGFBP1) to Promote Angiogenesis. J. Boil. Chem. 2015, 290, 23401-23415. [CrossRef] [PubMed]

63. Feng, X.; Lin, J.; Xing, S.; Liu, W.; Zhang, G. Higher IGFBP-1 to IGF-1 serum ratio predicts unfavourable survival in patients with nasopharyngeal carcinoma. BMC Cancer 2017, 17, 90. [CrossRef] [PubMed]

64. Ruf, W.; Schaffner, F. Role of the protein C receptor in cancer progression. Thromb. Res. 2014, 133, S85-S89. [CrossRef]

65. Althawadi, H.; Alfarsi, H.; Besbes, S.; Mirshahi, S.; Ducros, E.; Rafii, A.; Pocard, M.; Therwath, A.; Soria, J.; Mirshahi, M. Activated protein C upregulates ovarian cancer cell migration and promotes unclottability of the cancer cell microenvironment. Oncol. Rep. 2015, 34, 603-609. [CrossRef]

66. Wang, D.; Liu, C.; Wang, J.; Jia, Y.; Hu, X.; Jiang, H.; Chen, S.; Zeng, Y.A. Protein C receptor stimulates multiple signaling pathways in breast cancer cells. J. Boil. Chem. 2017, 293, 1413-1424. [CrossRef]

67. Wang, D.; Cai, C.; Dong, X.; Yu, Q.C.; Zhang, X.O.; Yang, L.; Zeng, Y.A. Identification of multipotent mammary stemcells by protein $C$ receptor expression. Nature 2015, 517, 81-84. [CrossRef]

68. Ducros, E.; Mirshahi, S.; Azzazene, D.; Camilleri-Broët, S.; Mery, E.; Al Farsi, H.; Althawadi, H.; Besbess, S.; Chidiac, J.; Pujade-Lauraine, E.; et al. Endothelial protein $C$ receptor expressed by ovarian cancer cells as a possible biomarker of cancer onset. Int. J. Oncol. 2012, 41, 433-440. [CrossRef]

69. Stewart, G.D.; Skipworth, R.J.E.; Pennington, C.J.; Lowrie, A.G.; Deans, D.A.C.; Edwards, D.R.; Habib, F.K.; Riddick, A.C.P.; Fearon, K.C.H.; Ross, J.A. Variation in dermcidin expression in a range of primary human tumours and in hypoxic/oxidatively stressed human cell lines. Br. J. Cancer 2008, 99, 126-132. [CrossRef]

70. Meng, Y.; Lu, Z.; Yu, S.; Zhang, Q.; Ma, Y.; Chen, J. Ezrin promotes invasion and metastasis of pancreatic cancer cells. J. Transl. Med. 2010, 8, 61. [CrossRef]

71. Wu, Y.; Sun, L.; Zou, W.; Xu, J.; Liu, H.; Wang, W.; Yun, X.; Gu, J. Prosaposin, a regulator of estrogen receptor alpha, promotes breast cancer growth. Cancer Sci. 2012, 103, 1820-1825. [CrossRef]

72. Ortega-Martínez, I.; Gardeazabal, J.; Erramuzpe, A.; Sanchez-Diez, A.; Cortés, J.; García-Vázquez, M.D.; Pérez-Yarza, G.; Izu, R.; Diaz, J.M.C.; De La Fuente, I.M.; et al. Vitronectin and dermcidin serum levels predict the metastatic progression of AJCC I-II early-stage melanoma. Int. J. Cancer 2016, 139, 1598-1607. [CrossRef]

73. Brauer, H.A.; D’Arcy, M.; Libby, T.E.; Thompson, H.J.; Yasui, Y.Y.; Hamajima, N.; Li, C.I.; Troester, M.A.; Lampe, P.D. Dermcidin expression is associated with disease progression and survival among breast cancer patients. Breast Cancer Res. Treat. 2014, 144, 299-306. [CrossRef]

74. Capello, M.; Cappello, P.; Linty, F.C.; Chiarle, R.; Sperduti, I.; Novarino, A.; Salacone, P.; Mandili, G.; Naccarati, A.; Sacerdote, C.; et al. Autoantibodies to Ezrin are an early sign of pancreatic cancer in humans and in genetically engineered mouse models. J. Hematol. Oncol. 2013, 6, 67. [CrossRef]

75. Jiang, Y.; Zhou, J.; Luo, P.; Gao, H.; Ma, Y.; Chen, Y.-S.; Li, L.; Zou, D.; Zhang, Y.; Jing, Z. Prosaposin Promotes the Proliferation and Tumorigenesis of Glioma Through Toll-Like Receptor 4 (TLR)-Mediated NF-Kb Signaling Pathway. SSRN Electron. J. 2018, 37, 78-90. [CrossRef]

76. Ishihara, S.; Inman, D.R.; Li, W.-J.; Ponik, S.M.; Keely, P.J. Mechano-Signal Transduction in Mesenchymal Stem Cells Induces Prosaposin Secretion to Drive the Proliferation of Breast Cancer Cells. Cancer Res. 2017, 77, 6179-6189. [CrossRef] 
77. Koochekpour, S.; Hu, S.; Vellasco-Gonzalez, C.; Bernardo, R.; Azabdaftari, G.; Zhu, G.; Zhau, H.E.; Chung, L.W.; Vessella, R.L.; Azabdaftari, G.; et al. Serum prosaposin levels are increased in patients with advanced prostate cancer. Prostate 2011, 72, 253-269. [CrossRef]

78. Chen, R.; Kang, R.; Fan, X.-G.; Tang, D. Release and activity of histone in diseases. Cell Death Dis. 2014, 5, e1370. [CrossRef]

79. Wu, D.; Ingram, A.; Lahti, J.H.; Mazza, B.; Grenet, J.; Kapoor, A.; Liu, L.; Kidd, V.J.; Tang, D. Apoptotic Release of Histones from Nucleosomes. J. Boil. Chem. 2002, 277, 12001-12008. [CrossRef] 